\title{
Leptin Receptor and Prolactin Are Prognostic Factors for Pubertal Disorders in Male Adolescents With Advanced Chronic Kidney Disease
}

\author{
MA. Villasís-Keever \\ Instituto Mexicano del Seguro Social \\ Jessie Zurita-Cruz ( $\nabla$ zuritajn@hotmail.com ) \\ Hospital Infantil de Mexico Federico Gomez \\ Juana Serret-Montoya
}

Federico Gomez Children's Hospital of Mexico: Hospital Infantil de Mexico Federico Gomez

DC. Zepeda-Martinez

Instituto Mexicano del Seguro Social

Gabriela Alegria-Torres

Instituto Mexicano del Seguro Social

Aly Sugey Barradas-Vazquez

Instituto Mexicano del Seguro Social

BC. Hernández-Hernández

Instituto Mexicano del Seguro Social

\section{SR. Alonso-Flores}

Instituto Mexicano del Seguro Social

\section{Manuel-Apolinar}

Instituto Mexicano del Seguro Social

\section{Damasio-Santana}

Instituto Mexicano del Seguro Social

\section{Research article}

Keywords: adolescent, chronic kidney disease, pubertal disorder, receptor leptin

Posted Date: January 15th, 2021

DOI: https://doi.org/10.21203/rs.3.rs-146240/v1

License: (c) (1) This work is licensed under a Creative Commons Attribution 4.0 International License.

Read Full License 


\section{Abstract}

Background: Few research studies have assessed chronic kidney disease (CKD) with pubertal disorders (PD) in adolescent boys and limited data are available. Thus, this study was planned to identify the usefulness of assessing hormonal parameters in male adolescents with CKD and their relationship with PD with a 1-y follow-up period.

Methods: A prospective cohort study was performed on adolescents with CKD, stages IV and V. We collected information about the age at puberty onset, menarche, and the date of last menstrual period from the subjects' clinical records and interrogation. A 1-y follow-up was conducted over pubertal development. At the beginning of the follow-up, the routine hormonal profile tests were performed to check the thyroid profile, prolactin level, luteinizing hormone level, follicle-stimulating hormone level, testosterone level, leptin level, and receptor leptin level. We compared the hormonal profiles of patients with and without PD (WPD vs. woPD). Comparisons between the groups were made using Wilcoxon and Fisher's tests. Logistic regression analysis was also performed.

Results: Sixty-four patients, including 26 patients who were classified into the WPD group were analyzed. The median age of the study population was $15 \mathrm{y}$, and the median time for CKD evolution was 11 mon. There were no differences in the general and biochemical characteristics of WPD and woPD subjects. In terms of the hormonal measurements, the levels of prolactin were higher, while those of free leptin and free thyroxine were lower in wPD patients. Leptin receptor levels $>0.90 \mathrm{ng} / \mathrm{mL}(\mathrm{RR} 8.6 \mathrm{p}=0.004)$ and hyperprolactinemia (RR $21.3 p=0.049)$ were risk factors for the development of PD.

Conclusions: Leptin receptor levels $<0.90 \mathrm{ng} / \mathrm{mL}$ and hyperprolactinemia are associated with the development of PD in male adolescents with CKD.

\section{Background}

Patients with chronic kidney disease (CKD) experience several health issues that commonly remained undetected (1). For several y, CKD has been associated with neuroendocrine disorders, growth deceleration, and sexual dysfunction, all of which may appear at puberty $(1-3)$.

Delayed puberty is defined as the absence of testicular growth (testicular volume $<4 \mathrm{~mL}$ ) at the beginning of the development of sexual characteristics, specifically in boys, older than $14 \mathrm{y}$ of age (4). Among the manifestations that would be expected in male patients is delayed puberty or arrest in the development of puberty secondary to hypogonadism; in this regard, the changes are subtle, since the decrease in the progression of puberty would be observed when identifying that there is no increase in testicular volume in an average of 6-8 mon (5). The reported prevalence of hypogonadism is $24-66 \%$, and this can improve for up to $2 \mathrm{y}$ after kidney transplantation, with hypogonadism persisting in up to $25 \%$ of the patients $(6-8)$. 
The pathophysiology of pubertal disorders (PD) in men with CKD is multifactorial (9). Factors include the absence of adequate cyclical release of gonadotropin-releasing hormone $(\mathrm{GnRH})$ from the hypothalamus, leading to loss of the normal pulse of luteinizing hormone $(\mathrm{LH})$, with decreased testosterone secretion by the testis resulting in decreased testosterone levels $(1,2,10)$. With the progression of kidney disease, hypogonadotrophic hypogonadism sets in, with increased risk of renal osteodystrophy (11). Further, hyperprolactinemia has been observed in up to $80 \%$ of CKD patients owing to increased production and decreased clearance that may cause higher gonadotropin suppression, leading to decreased testosterone secretion and sexual dysfunction $(10,12)$. The presence of a pathological thyroid profile, including clinical or subclinical hypothyroidism, can also cause alterations in the hypothalamic-pituitary-gonadal axis and can manifest as PD.

Leptin is a peptide hormone (13) that is mainly synthesized by the adipose tissue (14), is regulated by hypothalamic neuropeptides involved in energy metabolism (15), and has been linked to the onset of puberty. The adipokine leptin realizes signal transduction via four different leptin receptor (sOB-R) isoforms (16). Concentrations of SOB-R are differentially regulated in metabolic disorders; therefore, they can enhance or reduce leptin sensitivity (17). The measurements in the serum of lean or even anorexic subjects revealed increased SOB-R concentrations and suggest that acute and chronic dysregulations of energy homeostasis may influence sOB-R generation (18).

The presence of pubertal alterations is common in CKD patients; however, the clinical changes are subtle in men than in women, making their identification difficult (10). In addition, hormonal factors that can predict its appearance in male adolescents with CKD have not been precisely identified. Thus, this study aimed to identify the factors related to the development of pubertal disorders at the 1-y follow-up in male adolescents with CKD.

\section{Methods}

A prospective cohort study was performed from December 2016 to January 2020 at two tertiary pediatric care centers in Mexico City. For 12 months, we followed up a cohort of boys aged $>12 \mathrm{y}$ with CKD stages 4 and 5 as per KDIGO's staging scale (19) who were undergoing peritoneal dialysis or hemodialysis and had a history of onset of pubertal development, evaluated with a testicular volume $>4 \mathrm{~mL}$. All the patients included were selected using the consecutive sampling technique. Patients who did not agree to participate or had incomplete clinical and biochemical evaluations were excluded.

\section{Subjects}

We selected 88 patients aged $>12$ y old; however, 12 patients were 12-14 y old with Tanner stages 1 and bone age slightly delayed with the chronological (delay of less than a y) and according to the normal variability of the onset of puberty, they were still within normal limits not to start it, six patients were $17 \mathrm{y}$ old with Tanner stage 1 with bone age delayed by more than $3 y$ with respect to chronology and classified 
as having delay puberty, four patients did not agree to participate and during follow-up two patients did not attend the control consultations. Ultimately, 64 patients were included.

Leptin, leptin receptor, biochemical, and hormonal studies were performed at the beginning of the followup. Hormonal studies were performed at 6 and 12 months of the follow-up. At the beginning, at 6 and 12 months of follow-up, the testicular volume was evaluated. Hormonal examinations were repeated at 6 and 12 months of the follow-up for patients who had hyperprolactinemia or hypothyroidism.

\section{Etiological diagnosis as per the hormonal profile}

Subclinical hypothyroidism was defined by elevated serum thyroid stimulant hormone (TSH) (6-9.9 $\mu \mathrm{U} / \mathrm{mL}$ ) and normal free thyroid hormones (20), and hypothyroidism was defined as the presence of normal or low free thyroid hormones and TSH $>10 \mu \mathrm{U} / \mathrm{mL}$. Hyperprolactinemia was diagnosed when prolactin levels were $>25 \mathrm{ng} / \mathrm{mL}(21)$.

\section{Hemodialysis and peritoneal dialysis treatment adequacy and residual renal function}

In order to determine and quantify the hemodialysis and peritoneal dialysis treatment adequacy, the $\mathrm{Kt} / \mathrm{V}$ was calculated ( $K$ : dialyzer clearance of urea, $t$. dialysis time and $V$ : volume of distribution of urea) (22, 23). For patients with CKD stage IV, the glomerular filtration rate was calculated (24).

\section{Serum hormones and biochemistry level measurements}

At the beginning of the study, the 12-hour fasting serum hormone levels of the patients were measured between $7 \mathrm{AM}$ and $8 \mathrm{AM}$. LH, follicle stimulant hormone (FSH), testosterone, prolactin, TSH, total triiodothyronine (T3t), total thyroxine (T4t), free thyroxine (FT4) and free triiodothyronine (FT3) levels were measured using electrochemiluminescence immunoassay (ECLIA). The macroprolactin level of the patients was not measured.

Leptin and leptin receptor levels were measured using an enzyme-linked immunosorbent assay (ELISA) (Human Leptin Duo Set, DY 398, Human Leptin Receptor, CAT DY 389, R\&D Systems, Minneapolis, MN, USA). The plates were assessed using an ELISA microplate reader (Labsystems Multiskan EX, MTX Labsystems Inc., Vienna, VA) and were assessed in duplicate as per the manufacturer's instructions. Intraand interassay coefficients of variation $<7 \%$ were considered acceptable. A standard curve was also generated for each assay. Free leptin levels were calculated by dividing the total leptin concentrations by the leptin receptor concentrations.

25-Hydroxy-vitamin D was measured using chemiluminescence (Roche-Hitachi Modular P and D). Hemoglobin, urea, creatinine, and parathyroid hormone levels were measured using a colorimetric enzymatic method (IN-REACT, SPIM120). All the ECLIA experiments were performed using COBAS 6000 e601 (Roche Diagnostics $\mathrm{GmbH}$, Indianapolis, IN, USA) in duplicate as per the manufacturer's recommendations. 


\section{Anthropometry}

A certified nutritionist recorded the anthropometric indicators of each patient. Height was measured with the stadiometer SECA model 769. For weight and body fat percentage measurements, we used the bio impedance method (Tanita BC-568 Segmental Body Composition Monitor, Tokyo, Japan); the patients were barefoot and wearing underwear, as described elsewhere. Testicular volume was measured by comparing the patient's testicular volume with already determined ellipsoid models of $1,2,3,4,5,6,8,10$, $12,15,20,30$, and 35 with the Prader Orchidometer (Erler-Zimmer Model OM20 Plastic, Germany).

\section{Pubertal disorders (PD)}

Pubertal disorder was defined when at 6 or 12 months of follow-up, it was identified without modification in the testicular volume, and in the case of patients with Tanner stage 2 and 3 , the testosterone levels would have decreased as per the initial serum levels. In the case of patients with Tanner stage 4, the testosterone level was $<2.64 \mathrm{ng} / \mathrm{mL}$, in addition to serum LH levels $<0.6 \mu \mathrm{U} / \mathrm{mL}$ and FSH in low limits according to the cut-off point of the laboratory standard (25).

Pubertal delay was defined as age of $14 \mathrm{y}$ and Tanners stage 1 that was equivalent to the absence of testicular growth (testicular volume $<4 \mathrm{~mL}$ ) (26). In addition to the determination of baseline $\mathrm{LH}<$ $0.6 \mu \mathrm{U} / \mathrm{mL}$, plus post-LH LH). stimulus $<5 \mu \mathrm{U} / \mathrm{mL}$, and testosterone $<2.65 \mathrm{ng} / \mathrm{mL}(5,25)$.

The research protocol was approved by the Ethics and Research Committee of the both hospitals under numbers R-2014-3603-30 and HIM 2017 - 131 FF. The parents signed informed consent, and the adolescents signed the informed consent letter.

\section{Statistical analyses}

The Shapiro-Wilk test was applied to the quantitative variables, and a nonparametric distribution was observed. We calculated the medians and ranges of the quantitative variables. In order to determine the differences in the serum hormones and biochemistry levels between WPD and woPD subjects, an analysis was performed using the Wilcoxon test. For differences between the hormonal diagnoses (thyroid dysfunction and hyperprolactinemia), Fisher's test was applied to compare the proportions between the groups.

An ROC curve was performed with the serum receptor leptin levels to identify the cut-off point with the best sensitivity and specificity, correct classification, and positive likelihood ratio $(L R+)$ to diagnose PD during the 12-mon follow-up. With the results of the ROC curve, considering the best cut-off point of $0.90 \mathrm{ng} / \mathrm{mL}$ for leptin receptor, logistic regression analysis was used to determine the relationship between patients with leptin receptor levels $>0.90 \mathrm{ng} / \mathrm{mL}$ and PDs adjusted by hyperprolactinemia, T4t, urea, fat body and age of beginning at CKD; $p<0.05$ was considered statistically significant. STATA v.11.0 was used for the statistical analyses. 


\section{Results}

Sixty-four patients with CKD aged 12-17 y were included; the median patient age was $15 \mathrm{y}$. The most frequent CKD etiologies were genitourinary malformations in 46 patients $(71.8 \%)$. At the time of evaluation, 12 patients (18.8\%) were in stage 4 of CKD, and $52(81.2 \%)$ were in stage 5 . Of the stage 5 patients, $36(69.2 \%)$ were undergoing hemodialysis as replacement treatment, and $16(30.8 \%)$ were undergoing peritoneal dialysis (Table 1 ).

Forty-eight of the 64 patients (75\%) had a normal nutritional status; 10 were malnourished, and 6 were overweight or obese. Moreover, during the physical examination, 22 patients (34.4\%) had a testicular volume of $4 \mathrm{~mL}, 4(6.2 \%)$ had a volume of $6 \mathrm{~mL}, 7(11 \%)$ had a volume of $10 \mathrm{~mL}, 11(17.2 \%)$ had a volume of $12 \mathrm{~mL}, 8(12.5 \%)$ had a volume of $15 \mathrm{~mL}$, and $12(18.3 \%)$ had a volume of $20 \mathrm{~mL}$; thus, most patients were in Tanner stage $2(n=26,40.6 \%)$, although $26(40.6 \%)$ were in Tanner stage 3 , and 12 (18.8\%) were in Tanner stage 4.

At the beginning, six patients were identified as having delayed puberty. Of the patients for whom follow up was started, it was confirmed at the beginning that the patients had started the pubertal outbreak and that the testosterone levels were within the normal limits. At 6 months of follow-up, 22 patients did not present an increase in the testicular volume (16 were in Tanner stage 2 and 6 were in Tanner stage 3 ). In all the patients, the serum testosterone, LH, and FSH levels decreased as compared to that in the first evaluation. At 12 months of follow-up, 4 patients who were in Tanner stage 4, who at the beginning of the follow-up and at 6 months had a testicular volume of $20 \mathrm{~mL}$, as well as a decrease in the serum levels of LH, FSH and testosterone (Fig. 1). At the end of the follow-up, 26 patients had an alteration in puberty.

\section{Comparison of the general and biochemical characteristics between adolescents with CKD who did and did not have pubertal disorders (WPD vs. woPD)}

There was no difference in the age, BMI z-scores, time of CKD evolution, CKD etiology, CKD stage, and replacement treatment of the WPD and woPD subjects; however, WPD subjects had lower body fat and bone age. With respect to the biochemical studies, wPD patients had lower hemoglobin concentrations (mediated wPD $10.2 \mathrm{~g} / \mathrm{dL}$ vs. woPD $11.8 \mathrm{~g} / \mathrm{dL}$ ); the other biochemical parameters were comparable (Table 1).

\section{Comparison in the hormonal measurements and hormone disorders between adolescents with CKD and wPD vs. woPD}

The hormonal measurements of the included patients were analyzed; $7.69 \%(n=2)$ patients had subclinical hypothyroidism, and $12.5 \%(n=8)$ had hyperprolactinemia.

When the hormonal measurements between the wPD and woPD patients were compared, it was determined that the serum prolactin concentrations (median $19.2 \mathrm{ng} / \mathrm{mL}$ vs. $18.1 \mathrm{ng} / \mathrm{mL} \mathrm{p}=0.016$ ) were higher in wPD patients, T4t concentrations (median $1.43 \mu \mathrm{U} / \mathrm{mL}$ vs. $2.36 \mu \mathrm{U} / \mathrm{mL}, p=0.03$ ) were lower in the wPD, and more wPD patients had hyperprolactinemia (woPD $n=0,0 \%$ vs. woPD $n=8,30.7 \% p<$ 
0.001). In contrast, the total leptin levels $(4.19 \mathrm{ng} / \mathrm{dL}$ vs. $3.66 \mathrm{ng} / \mathrm{dL}, \mathrm{p}=0.978)$ were not different between the groups; however, free leptin was lower in the wPD patients than in woPD patients (3.16 ng/dL vs. $22.1 \mathrm{ng} / \mathrm{dL} \mathrm{p}=0.009$ ) (Table 3).

During the follow-up period, eight patients WPD and hyperprolactinemia were referred to the pediatric endocrinology service where they were followed up for PD and hyperprolactinemia; during this follow-up, the patients did not show changes in the prolactin levels. However, in patients with subclinical hypothyroidism, a new thyroid profile was determined at 6 mon of follow-up, where levels of TSH and thyroid hormones were normalized, without any hormonal treatment.

ROC curve analysis was performed to identify the best cut-off level of serum leptin receptor levels to predict the presence of PD in the analyzed patients and the best cut-off level of serum leptin receptor was $>0.90 \mathrm{ng} / \mathrm{mL}$ with the highest percentage of correct classification (sensitivity $84.6 \%$, specificity $78.9 \%$, correct classification $81.2 \%$, LR + 4.01).

With this cut-off point, multivariate logistic regression analysis was performed to identify the factors related to the presence or development of PD in CKD patients. Leptin receptor $>0.90 \mathrm{ng} / \mathrm{mL}(\mathrm{RR} 8.6 \mathrm{p}=$ 0.002) and hyperprolactinemia (RR $21.3 p=0.49$ ) were risk factors, independent of the levels of urea, $T 4 t$, body fat percentage, and CKD evolution time (Table 3 ).

\section{Discussion}

\section{Main findings}

The frequency of pubertal alterations in male patients was $45.7 \%$ (6 patients at the beginning of the study had delayed puberty and 26 had puberty arrest during follow-up). Of the hormonal alterations that the patients presented, hyperprolactinemia and high levels of the leptin receptor were related to PD development. However, the diagnosis of CKD at an early age was more frequent in PD patients.

The presence of hypogonadism is a common finding in end-stage CKD patients and those with kidney transplantation $(26,27)$. The etiology is multifactorial and the term "uremic hypogonadism" has been coined to describe the hormonal status associated with kidney disease. Patients with stage V CKD have protein loss (loss of muscle mass) and low concentrations of serum albumin, transferrin, and prealbumin; all this is secondary to various factors, such as anorexia, nausea, and vomiting associated with uremia, administration of medications, hormonal disorders, acidosis and increased energy expenditure that reduces the muscle mass, and consequently malnutrition $(28,29)$. Pubertal initiation and development require a greater amount of energy from the body; therefore, the initiation and progression of puberty is compromised in malnourished subjects; this results in functional hypogonadotrophic hypogonadism $(30,31)$.

Although no difference was identified in the nutritional status of patients with and without PD; the percentage of fat and free leptin was lower in wPD patients. There is considerable metabolic 
heterogeneity between the different adipose stores. Therefore, proteins secreted by the adipose tissue are actively involved in energy homeostasis and regulation of autonomic neuroendocrine function; the endocrine role of adipose tissue is better characterized by leptin (32). Leptin transmits information to the brain about the stored energy available, acts through its receptor to stimulate the secretion of kisspeptin, a hypothalamic hormone that promotes GnRH secretion (33), although it is not clear if it is a direct action on kisspeptin-neurokinin B-dynorphin neurons or if leptin acts through an intermediate cell (34). Thus, the importance of leptin in puberty has been indicated and it has been implicated as a factor that contributes to puberty abnormalities in CKD patients $(35,36)$. Although we found no difference in the serum levels of total leptin, if we observe the low levels of free leptin in wPD patients and a correlation between growth and sexual maturation parameters has been demonstrated in men, with free leptin, without identifying a direct correlation with body fat (18). In contrast, in populations with a negative energy balance due to insufficient caloric consumption with respect to energy expenditure, the serum leptin receptor levels are increased; this may represent a protective mechanism that decreases free leptin bioavailability that would further conserve energy (37).

Thus, it is necessary to monitor the nutritional status regularly in all children and especially in those with a chronic disease that compromises their health, such as CKD, because it is known that malnutrition is a serious problem and a common complication in these patients that is associated with increased morbidity and mortality $(30,38,39)$.

Hyperprolactinemia was also a risk factor for PD development in male adolescents with CKD. Hyperprolactinemia causes disturbances in the concentration of dopamine, inhibiting the secretion of $\mathrm{GnRH}$ and consequently the pulsatile secretion of LH and FSH $(40,41)$. A direct action of hyperprolactinemia at the level of Leydig cells is suggested, suppressing testosterone secretion $(6,42)$. Finally, this produces functional hypogonadotropic hypogonadism in CKD patients (7).

Hyperprolactinemia is a multifactorial condition in this population, and probably the management that could be offered is an increase in dialyxzacy to increase prolactin clearance or drugs that decrease prolactin levels, which in both cases should be evaluated. the risk-benefit balance (21).

Although, when renal functionality was compared in patients with and without pubertal impairment, no relevance was documented in the uremic status, bone mineral metabolism, or anemic status, it is important to note that puberty depends on several conditions $(2,43)$, and we probably did not show a difference owing to the sample size and the differences in these parameters are probably less evident than in hormonal alterations.

Delayed puberty, especially in boys, can have significant psychosocial repercussions $(25,44)$. In a time of extreme sensitivity and psychological liability, where body image is very important for the self-esteem of the subject, the lack of pubertal development and short stature, which frequently accompanies pubertal delay, can cause low self-esteem, depressive behaviors, and reaching poor adherence to renal replacement therapy $(1,45)$. While managing these patients, the use of testosterone is not recommended, as in adults (45) because the premature closure of the growth plates may occur, resulting in short stature, 
greater than that already present in these patients (46). The ideal approach would be early kidney transplantation early; however, in developing countries this is complicated; thus, the multidisciplinary management of these patients becomes a challenge.

Based on these results, we recommend that all patients aged $>10 \mathrm{y}$ with stage 4 and 5 CKD should undergo extensive physical examination, including testicular examination and correlate biochemically with the hormonal profile for early identification of factors that alter pubertal development and in addition to assessing, improve nutritional conditions, and in case of presenting hyperprolactinemia, perform interventions to lower serum prolactin levels.

The fact that only body fat was determined and not the entire body composition including muscle mass, which in the present cohort would be vital, was a study limitation. The relatively small sample size however, according to the group studied and the inclusion criteria, the population is restricted.

\section{Conclusion}

The factors related to the development of pubertal disorders at the 1-y follow-up in male adolescents with CKD were hyperprolactinemia and high leptin receptor levels.

\section{Abbreviations}

with chronic kidney disease (CKD)

pubertal disorders (PD)

leptin receptor (OB-R)

with pubertal disorders (WPD)

without pubertal disorders (WoPD)

\section{Declarations}

\section{Ethics approval and consent to participate}

According to the Helsinki Declaration, the protocol was approved by the National Research Ethics Committee, which belongs to the Mexican Institute of Social Security and Hospital Infantil de México Federico Gómez. This committee is the body in charge of evaluating research projects at the national level. The registry number R-2014-785-024 and HIM 2017-131 FF.

\section{Informed consent}

According to the Helsinki Declaration, the protocol was approved by the National Research Ethics Committee, which belongs to the Mexican Institute of Social Security and Hospital Infantil de México 
Federico Gómez. This committee is the body in charge of evaluating research projects at the national level. The registry number R-2014-785-024 and HIM 2017-131 FF. The parent or legal guardian signed a written informed consent form, and each child provided a written assent according to the recommendations of the Declaration of Helsinki.

\section{Consent to publish}

Not applicable

\section{Availability of data and materials}

The datasets generated and/or analyzed during the current study are not publicly available due, but are available from the corresponding author on reasonable request.

\section{Competing interests}

The authors declare that they have no competing interests.

\section{Funding}

This work was supported by a Mexican Federal Funds Grant (HIM 2017/131). The funder role was analysis of the patient's lipid profile.

\section{Author contributions}

JNZC analyzed, interpreted the data and wrote the article. JSM, DCZM \& GAT analyzed and interpreted the data. ASBV, BCHH, SRAF, LMA \& LDS provided the critical review for important intellectual content, wrote the discussion and approved the final version of the article. MAVK designed the study design and acquired information. All authors have read and approved the manuscript.

\section{Acknowledgments}

Not applicable

\section{References}

1. Lane PH. Puberty and chronic kidney disease. Adv Chronic Kidney Dis. 2005;(12):372-7.

2. Biff F. Endocrine Disorders in Renal Failure. In: Elsevier, editor. Textbook of Nephro-Endocrinology. EUA; 2009. p. 437-9.

3. Anantharaman P SR. Sexual function in chronic kidney disease. Adv Chronic Kidney Dis. 2007; (14):119-25.

4. Klein DA, Emerick JE, Sylvester JE VK. Disorders of Puberty: An Approach to Diagnosis and Management. Am Fam Physician. 2017;96(9):590-9. 
5. Maggi M, Buvat J. Standard Operating Procedures: Pubertas Tarda/Delayed Puberty-Male. J Sex Med. 2013;10(1):285-93.

6. Iglesias P, Carrero JJ DJ. Gonadal dysfunction in men with chronic kidney disease: clinical features, prognostic implications and therapeutic options. J Nephrol. 2012;25(1):31-42.

7. Neuzillet $Y$, Thuret R, Kleinclauss F TM. Andrologic consequences of chronic renal failure: State of the art for the yearly scientific report of the French National Association of Urology. Prog Urol. 2016;26(15):1088-93.

8. Bao Y JK. Diagnosis and Treatment of Low Testosterone among Patients with End-Stage Renal Disease. Semin Dial. 2015;28(3):259-65.

9. Haffner D, Zivicnjak M. Pubertal development in children with chronic kidney disease. Pediatr Nephrol [Internet]. 2017;32(6):949-64. Available from: http://dx.doi.org/10.1007/s00467-016-3432-3

10. Holley J. The hypothalamic-pituitary axis in men and women with chronic kidney disease. Adv Chronic Kidney Dis. 2004;11:331-7.

11. Lim V, Auletta F, Kathpalia S FL. Gonadal function in women with chronic renal failure: A study of the hypothalamo-pituitary-ovarian axis. Proc Clin Dial Transpl Forum. 1977;7:39-47.

12. Holley J, Schmidt R, Bender FH, Dumler F SM. Gynecologic and reproductive issues in women on dialysis. Ame J Kidney Dis. 1997;29:685-90.

13. Baptista C. Leptina (Leptin). Acta Pediatr Port. 2002;15:281-285.

14. Friedman JM, Halaas JL. Leptin and the regulation of body weight in mammals. Nature. 1998;395(6704):763-70.

15. Longas AF. Leptina y pubertad. 1998;49:561-7.

16. Huang L, Wang Z LC. Modulation of circulating leptin levels by its soluble repector. J Biol Chem 2001. 2001;276:6343-9.

17. Schaab M, Kratzsch J. The soluble leptin receptor. Best Pr Res Clin Endocrinol Metab. 2015;29(5):661-70.

18. Kratzsch J, Lammert A, Bottner A, Seidel B, Mueller G, Thiery J, Hebebrand J KW. Circulating soluble leptin receptor and free leptin index during childhood, puberty, and adolescence. J Clin Endocrinol Metab. 2002;87(10):4587-94.

19. Inker LA, Astor BC, Fox CH, Isakova T, Lash JP, Peralta CA, et al. KDOQI US commentary on the 2012 KDIGO clinical practice guideline for the evaluation and management of CKD. Am J Kidney Dis. 2014;63(5):713-35.

20. Delitala A, Fanciulli G, Maioli M DG. Subclinical hypothyroidism, lipid metabolism and cardiovascular disease. Eur J Intern Med. 2017;38:17-24.

21. Halperin Rabinovich I, Cámara Gómez R, García Mouriz M OG-ADG de T de N de la S. Clinical guidelines for diagnosis and treatment of prolactinoma and hyperprolactinemia. Endocrinol Nutr. 2013;60:308-19. 
22. National Kidney Foundation. KDOQI Clinical Practice Guideline for Hemodialysis Adequacy: 2015 update. Am J Kidney Dis. 2015;66(5):884-930.

23. Slinin Y, Greer N, Ishani A, MacDonald R, Olson C, Rutks I WT. Timing of dialysis initiation, duration and frequency of hemodialysis sessions, and membrane flux: a systematic review for a KDOQI clinical practice guideline. Am J Kidney Dis. 2015;66(5):823-36.

24. Gorostidi M, Santamaría R, Alcázar R, Fernández-Fresnedo G, Galcerán JM, Goicoechea M, Oliveras A, Portolés J, Rubio E, Segura J, Aranda P, de Francisco AL, Del Pino MD, Fernández-Vega F, Górriz JL, Luño J, Marín R, Martínez I, Martínez-Castelao A, Orte L RL. Spanish Society of Nephrology document on KDIGO guidelines for the assessment and treatment of chronic kidney disease. Nefrologia. 2014;34(3):302-16.

25. Salonia A, Rastrelli G, Hackett G, Seminara SB, Huhtaniemi IT, Rey RA, Hellstrom WJG, Palmert MR, Corona G, Dohle GR, Khera M, Chan YM MM. Paediatric and adult-onset male hypogonadism. Nat Rev Dis Prim. 2020;5(1):1-49.

26. Gungor O, Kircelli F, Carrero JJ et al. Endogenous testosterone and mortality in male hemodialysis patients: is it the result of aging? Clin J Am Soc Nephrol. 2010;5:2018-23.

27. Albaaj F, Sivalingham M, Haynes $P$ et al. Prevalence of hypogonadism in male patients with renal failure. Postgr Med J. 2006;82:693-6.

28. Yılmaz D, Sönmez F, Karakaş S, Yavaşcan Ö, Aksu N, Ömürlü IK YÇ. Evaluation of Nutritional Status in Children during Predialysis, or Treated By Peritoneal Dialysis or Hemodialysis. J Trop Pediatr. 2016;62(3):178-84.

29. Gupta A, Mantan M SM. Nutritional assessment in children with chronic kidney disease. Saudi J Kidney Dis Transpl. 2016;27(4):733-9.

30. Foster B LM. Measuring nutritional status in children with chronic kidney disease. Am J Clin Nutr. 2004;80:801-14.

31. Cameron JL. Nutritional Determinants of Puberty. Nutr Rev. 1996;54:S17-22.

32. Hileman SM, Pierroz DD FJ. Leptin, nutrition and reproduction: timing is everything. J Clin Endocrinol Metab. 2000;85(2):804-807.

33. Wakabayashi Y, Nakada T, Murata K, Ohkura S, Mogi K, Navarro VM, Clifton DK, Mori Y, Tsukamura H, Maeda K, Steiner RA OH. Neurokinin B and dynorphin A in kisspeptin neurons of the arcuate nucleus participate in generation of periodic oscillation of neural activity driving pulsatile gonadotropinreleasing hormone secretion in the goat. J Neurosci. 2010;30(8):3124-32.

34. Donato J Jr, Cravo RM, Frazão R, Gautron L, Scott MM, Lachey J, Castro IA, Margatho LO, Lee S, Lee C, Richardson JA, Friedman J, Chua S Jr, Coppari R, Zigman JM, Elmquist JK EC. Leptin's effect on puberty in mice is relayed by the ventral premammillary nucleus and does not require signaling in Kiss1 neurons. J Clin Invest. 2011;121(1):355-68.

35. Ghazizadeh S. Lessan-Pezeshki M. Reproduction in women with end-stage renal disease and effect of kidney transplantation. Iran J Kidney Dis. 2007;1:12-5.

36. Wolf G, Chen S, Han DC ZF. Leptin and renal disease. Am J Kidney Dis. 2002;39(1):1-11. 
37. Donoso MA, Muñoz-Calvo MT, Barrios V, Garrido G, Hawkins F, Argente J. Increased circulating adiponectin levels and decreased leptin/soluble leptin receptor ratio throughout puberty in female ballet dancers: Association with body composition and the delay in puberty. Eur $\mathrm{J}$ Endocrinol. 2010;162(5):905-11.

38. Kuizon BD, Nelson PA SI. Tube feeding in children with end stage renal disease. Min Electrolyte Metab. 1997;23:306-10.

39. Kalantar-Zadeh $\mathrm{K}$ et al. A malnutrition-inflamation score is correlated with morbidity and mortality in maintenance hemodialysis patients. Am J Kidney Dis. 2001;38:1251-6.

40. Palmer BF CD. Gonadal dysfunction in chronic kidney disease. Rev Endocr Metab Disord. 2017;18(1):117.

41. Karagiannis A HF. Gonadal dysfunction in systemic diseases. Eur J Endocrinol. 2005;152:501-13.

42. Martin TL, Kim M MW. The natural history of idiopathic hyperprolactinemia. J Clin Endocrinol Metab. 1985;60(5):855-8.

43. Daschner M PB. Circulating inhibitor of gonadotropin releasing hormone secretion by hypothalamic neurons in uremia. Kidney Int. 2002;62:1582-90.

44. Klein DA, Emerick JE, Sylvester JE VK. Disorders of Puberty: An Approach to Diagnosis and Management. Am Fam Physician. 2017;96(9):590-9.

45. Thirumavalavan N, Wilken NA RR. Hypogonadism and renal failure: An update. Indian J Urol. 2015;31(2):89-93.

46. Van Steenbergen MW, Wit JM DR. Testosterone esters advance skeletal maturation more than growth in short boys with chronic renal failure and delayed puberty. Eur J Pediatr. 1991;150(9):67680.

\section{Tables}


Table 1.

General characteristics of the 64 analyzed patients with chronic kidney disease (CKD).

\begin{tabular}{|c|c|c|c|c|c|}
\hline & & $\begin{array}{l}\text { Total } \\
n=64\end{array}$ & $\begin{array}{l}\text { With puberal } \\
\text { disorder } \\
\mathrm{n}=26\end{array}$ & $\begin{array}{l}\text { Without puberal } \\
\text { disorder } \\
\mathrm{n}=38\end{array}$ & $\mathrm{p}$ \\
\hline & & Median (min- & ax) & & \\
\hline Age (years) & & $14(12-18)$ & $14(12-16)$ & $14.5(12-16)$ & 0.821 \\
\hline Bone age (year & & $13(10-19)$ & $12(10-19)$ & $13.6(10-16)$ & 0.006 \\
\hline Bone / chronol & al age relationship & $\begin{array}{l}1.03(0.79- \\
1.3)\end{array}$ & $1.1(0.79-1.3)$ & $1.0(0.94-1.2)$ & 0.301 \\
\hline Weight $(\mathrm{kg})$ & & $\begin{array}{l}40.7(23.9- \\
67.2)\end{array}$ & 30.8 (23.9-53) & $43.3(27.5-67.2)$ & 0.002 \\
\hline Stature $(\mathrm{cm})$ & & $\begin{array}{l}148(104- \\
171)\end{array}$ & $\begin{array}{l}134(104- \\
160)\end{array}$ & $157(130-171)$ & 0.001 \\
\hline BMI z Score & & $\begin{array}{l}-0.61(-2.42 \\
\text { a } 1.90)\end{array}$ & $\begin{array}{l}-0.61(-2.34 \mathrm{a} \\
1.90)\end{array}$ & $\begin{array}{l}-0.47(-2.42 \mathrm{a} \\
1.33)\end{array}$ & 0.931 \\
\hline Body fat (\%) & & $\begin{array}{l}18.9(12.8- \\
30.1)\end{array}$ & $\begin{array}{l}18.3(16.3- \\
24.0)\end{array}$ & $21(12.8-30.1)$ & 0.021 \\
\hline Age at diagnos & f CKD (years) & $10(0.1-15)$ & $9(3-15)$ & $12(1-15)$ & 0.025 \\
\hline Time of renal $r$ & cement (months)* & $11(1-122)$ & $11(0-122)$ & $11(1-60)$ & 0.705 \\
\hline Replacement & Pre-dialysis & $12(18.8)$ & $8(30.8)$ & $4(10.5)$ & 0.081 \\
\hline & Hemodialysis & $36(56.2)$ & $14(53.8)$ & $22(57.9)$ & \\
\hline & Peritoneal dialysis & $16(25.0)$ & $4(15.4)$ & $12(31.6)$ & \\
\hline CKD etiology* & Glomerulopathy & $12(18.75)$ & $6(16.7)$ & $6(21.4)$ & 0.075 \\
\hline & $\begin{array}{l}\text { Genitourinary } \\
\text { malformations }\end{array}$ & $46(71.88)$ & $24(66.6)$ & $22(78.6)$ & \\
\hline & Indeterminate & $6(9.38)$ & $6(16.7)$ & $0(0)$ & \\
\hline Hemoglobin (g & & $\begin{array}{l}11.4(5.2- \\
15.3)\end{array}$ & $\begin{array}{l}10.2(7.4- \\
15.3)\end{array}$ & $11.8(5.2-14.3)$ & 0.106 \\
\hline Urea (mg/dl) & & $\begin{array}{l}84.8(19.1- \\
364)\end{array}$ & $\begin{array}{l}84.8(19.1- \\
151)\end{array}$ & $88.7(48.1-364)$ & 0.935 \\
\hline Paratohormon & $\mathrm{g} / \mathrm{dl})$ & $\begin{array}{l}355.5(0.95- \\
2410)\end{array}$ & $\begin{array}{l}362(0.95- \\
2410)\end{array}$ & 355 (84-2010) & 0.956 \\
\hline Calcium (mg/d & & $\begin{array}{l}9.5(4.6- \\
10.9)\end{array}$ & $\begin{array}{l}9.35(8.1- \\
10.3)\end{array}$ & $9.55(4.6-10.9)$ & 0.551 \\
\hline
\end{tabular}




$\begin{array}{lllll}\text { Phosphorus (mg/dl) } & 5.4(1.9- & 5.3(3.2-9.0) & 5.4(1.9-11.5) & 0.664 \\ & 11.5) & & & \\ & & & \\ \text { 25-Hydroxy-vitamin D (ng/mL) } & 21.2(2.5- & \begin{array}{l}21.2(7.3- \\ \text { 58.0) }\end{array} & 21.5(3.5-58.0) & 0.684 \\ & 1.17(0.04- & 1.1(0.71- & 1.18(0.4-1.9) & 0.724 \\ \text { Kt/V (L/week) (n=54) } & 3.07) & 3.07) & & \\ & & \end{array}$

* $\mathrm{n}(\%)$

Table 2.

Hormonal profiles at beginning of the cohort on 64 analyzed patients with chronic kidney disease (CKD).

\begin{tabular}{|c|c|c|c|c|}
\hline & $\begin{array}{l}\text { Total } \\
\mathrm{n}=64\end{array}$ & $\begin{array}{l}\text { With puberal } \\
\text { disorder } \\
\mathrm{n}=26\end{array}$ & $\begin{array}{l}\text { Without puberal } \\
\text { disorder } \\
\mathrm{n}=38\end{array}$ & \\
\hline & \multicolumn{4}{|c|}{ Median (min-max) } \\
\hline Prolactin (ng/mL) & $\begin{array}{l}19.0 \\
327)\end{array}$ & $19.2(9.9-327)$ & $18.1(8.3-27.8)$ & 0.016 \\
\hline $\begin{array}{l}\text { Thyroid-stimulating hormone } \\
(\mu \mathrm{U} / \mathrm{ml})\end{array}$ & $\begin{array}{l}2.23(0.47- \\
7.57)\end{array}$ & $\begin{array}{l}1.90(0.80- \\
7.57)\end{array}$ & $2.65(0.47-4.2)$ & 0.193 \\
\hline Total thyroxine $(\mu \mathrm{g} / \mathrm{dl})$ & $\begin{array}{l}7.53(4.84- \\
10.1)\end{array}$ & $\begin{array}{l}7.10(4.84- \\
9.94)\end{array}$ & $7.86(4.86-10.86)$ & 0.255 \\
\hline Free thyroxine $(\mathrm{ng} / \mathrm{dl})$ & $\begin{array}{l}1.24(0.59- \\
8.14)^{-}\end{array}$ & $1.15(0.59-1.51)$ & $1.39(0.64-8.14)$ & 0.001 \\
\hline Total triiodothyronine $(\mathrm{ng} / \mathrm{dl})$ & $\begin{array}{l}1.16(0.63- \\
104.3)\end{array}$ & $\begin{array}{l}1.18(0.81- \\
104.31)\end{array}$ & $1.06(0.63-94.21)$ & 0.158 \\
\hline Free triiodothyronine $(\mathrm{pg} / \mathrm{ml})$ & $\begin{array}{l}2.78(1.85- \\
4.5)\end{array}$ & $2.75(2.17-3.73)$ & $2.95(1.85-4.50)$ & 0.357 \\
\hline Leptin (ng/ml) & $\begin{array}{l}3.68(0.58- \\
7.0)\end{array}$ & $4.19(0.58-7.0)$ & $3.66(1.37-6.56)$ & 0.978 \\
\hline $\begin{array}{l}\text { Leptin receptor (sOB-R) } \\
\text { (ng/ml) }\end{array}$ & $\begin{array}{l}0.57(0.05- \\
70.79)\end{array}$ & $\begin{array}{l}1.73(0.05- \\
70.79)\end{array}$ & $0.29(0.05-9.19)$ & 0.005 \\
\hline Free leptin & $\begin{array}{l}5.50(0.04- \\
137.2)\end{array}$ & $2.04(0.04-88.0)$ & $12.7(0.29-131.2)$ & 0.001 \\
\hline
\end{tabular}


Table 3.

Logistic regression analysis to PD at 12-month follow-up of patients with CKD $(n=64)$

\begin{tabular}{|llll|}
\hline Characteristics at beginning of the cohort & RR & IC 95\% & $p$ \\
\hline Leptin receptor (sOB-R) $<0.90 \mathrm{ng} / \mathrm{dl}$ & 8.60 & 1.97 a 37.5 & 0.004 \\
\hline Hyperprolactinemia & 21.3 & 1.01 a 256.5 & 0.049 \\
\hline Free Tiroxine $(\mathrm{ng} / \mathrm{dl})$ & 0.01 & 0.01 a 1.92 & 0.091 \\
\hline Urea $(\mathrm{mg} / \mathrm{dl})$ & 0.99 & 0.97 a 1.02 & 0.837 \\
Body fat $(\%)$ & 0.85 & 0.64 a 1.13 & 0.283 \\
\hline Age at diagnosis of CKD (years) & 0.94 & 0.80 a 1.11 & 0.539 \\
\hline
\end{tabular}

\section{Figures}
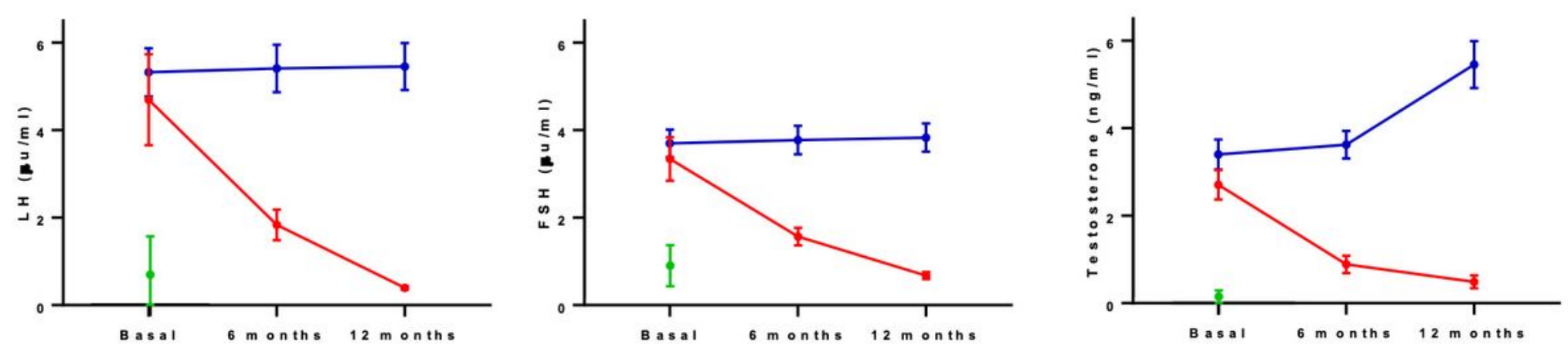

Figure 1

Description of serum concentrations of luteinizing hormone (LH), follicle-stimulating hormone (FSH) and testosterone in patients with delay puberty and during the 12 months of follow-up in patients with and without pubertal disorders. 